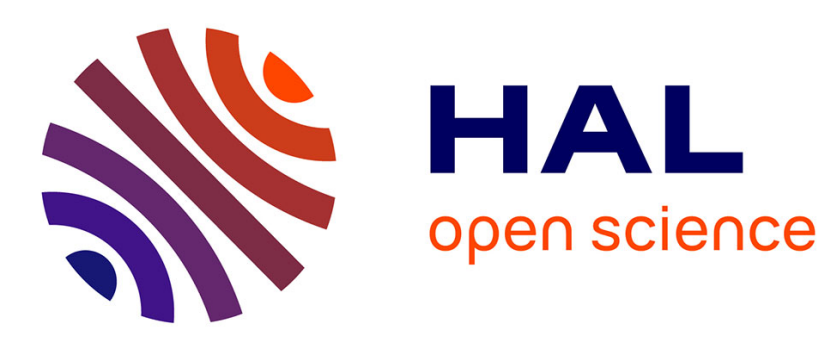

\title{
The social and spatial organisation of the beira antelope (): a relic from the past?
}

\author{
Nina Giotto, Jean-François Gérard
}

\section{To cite this version:}

Nina Giotto, Jean-François Gérard. The social and spatial organisation of the beira antelope (): a relic from the past?. European Journal of Wildlife Research, 2009, 56 (4), pp.481-491. 10.1007/s10344009-0326-8 . hal-00535255

\section{HAL Id: hal-00535255 \\ https://hal.science/hal-00535255}

Submitted on 11 Nov 2010

HAL is a multi-disciplinary open access archive for the deposit and dissemination of scientific research documents, whether they are published or not. The documents may come from teaching and research institutions in France or abroad, or from public or private research centers.
L'archive ouverte pluridisciplinaire HAL, est destinée au dépôt et à la diffusion de documents scientifiques de niveau recherche, publiés ou non, émanant des établissements d'enseignement et de recherche français ou étrangers, des laboratoires publics ou privés. 


\title{
The social and spatial organisation of the beira antelope (Dorcatragus megalotis): a relic from the past?
}

\author{
Nina Giotto • Jean-François Gerard
}

Received: 16 March 2009 /Revised: 1 September 2009 / Accepted: 17 September 2009 /Published online: 29 October 2009

(C) Springer-Verlag 2009

\begin{abstract}
We studied the social and spatial organisation of the beira (Dorcatragus megalotis) in arid low mountains in the South of the Republic of Djibouti. Beira was found to live in socio-spatial units whose ranges were almost nonoverlapping, with a surface area of about $0.7 \mathrm{~km}^{2}$. Each unit included a single adult male, and from one to three adult females. On average, the members of a unit made up a single group during $76 \%$ of the observation time, $92 \%$ outside the periods when a neonate was in the "hider" stage and/or an adult female in oestrus. Collective sequences of linked urination-defecation were frequent. Members of neighbouring units rarely met and interacted, chasing behaviour occurring mainly between adult males. Overall, the social and spatial organisation of the beira appears to be intermediate between that of the dik-diks (Madoqua spp.), in which units exceptionally include more than one adult female, and that of the oribi (Ourebia ourebi), in which units can include several adult males. Moreover, it resembles those of the klipspringer (Oreotragus oreotragus) and rhebok (Pelea capreolus), two morphologically conservative species that do not belong to the tribe Antilopini. We suggest that the beira's social and spatial organisation might be similar to that of the last common ancestor to the Antilopini, if not to most of the extant Antilopinae.
\end{abstract}

Communicated by W. Lutz

N. Giotto $(\bowtie) \cdot$ J.-F. Gerard Comportement et Ecologie de la Faune Sauvage, Institut National de la Recherche Agronomique, BP 52627, 31326 Castanet-Tolosan Cedex, France e-mail: nina_giotto@hotmail.com
Keywords Dwarf antelope · Group dynamics · Grouping pattern $\cdot$ Phylogeny Territory

\section{Introduction}

According to recent, detailed reconstructions of bovid phylogeny (Hernández Fernández and Vrba 2005; Ropiquet 2006), the tribe Antilopini (gazelles and relatives) includes a total of 13 extant genera (Antidorcas, Ammodorcas, Litocranius, Antilope, Nanger, Gazella, Eudorcas, Saiga, Procapra, Raphicerus, Madoqua, Ourebia, and Dorcatra$g u s)$. Most of these genera live in arid or semi-arid open landscape, and seasonally exhibit, if not year-round, a common type of social and spatial organisation: adult males hold territories over which adult females roam in groups of changing composition, and outside which "bachelor" males also make up unstable groups (Dubost and Feer 1981; Heptner et al. 1989; Estes 1991; Schaller 1998). However, and interestingly from a phylogenetic point of view, the four most morphologically conservative genera of the tribe (Gentry 1992; Hernández Fernández and Vrba 2005) tend to live in habitats that are as arid, but more closed, and exhibit alternative types of social and spatial organisation. The steenbok and grysboks (Raphicerus spp.) live solitary, or in very loose couples (Estes 1991), and at least in the steenbok (Raphicerus campestris) both adult males and females chase off outsiders of the same sex (Cloete and Kok 1990; Skinner and Chimimba 2005). The dik-diks (Madoqua spp.) live in couples, or exceptionally in trios including two adult females; the members of these social units are very often together, and intruders are primarily repelled from the common territory by the adult male (Hendrichs 1975; Brotherton and Rhodes 1996). The oribi (Ourebia ourebi) lives in couples or in small mixed-sex 
units sometimes including several adult males; unit members are together fairly often and, as in the previous genus, outsiders are primarily chased out of the common territory by the adult males (Monfort and Monfort 1974; Arcese et al. 1995). Finally, the beira (Dorcatragus megalotis) is reported to live in small mixed-sex groups with rarely more than one adult male (Dorst and Dandelot 1970; Laurent et al. 2002; Giotto et al. 2008).

The picture is, however, incomplete for the beira because of its rarity and use of inaccessible habitats. The beira is, indeed, a threatened species endemic to the arid mountains of the Horn of Africa (Northern Somalia, Northeastern Ethiopia, and Southern Djibouti; Künzel and Künzel 1998; Boitani et al. 1999; Laurent et al. 2002; Heckel et al. 2008). Whereas most authors agree that beira make up small mixed-sex groups, all-female groups (Giotto et al. 2008) and groupings of up to 12 animals (Walther 1990) have also been reported. Furthermore, group stability was only investigated during a lambing period, i.e., when group splitting necessarily occurs since neonates are "hiders" (Giotto et al. 2008). Adult males are assumed to be territorial on the basis of group composition and the observation of chasing behaviour (Giotto et al. 2008). Nonetheless, in the absence of any studies on space occupation, whether the adult males' behaviour leads to a mosaic of territories is unknown. Finally, beira are thought to live in definite socio-spatial units (Laurent et al. 2002), but little evidence has been reported in support of this assumption.

The purpose of the present study was to improve the knowledge of the beira's social and spatial organisation, and compare this organisation to those of the other "dwarf Antilopini" (i.e., the morphologically conservative genera Madoqua, Ourebia, and Raphicerus). On the basis of our findings and the literature, in the discussion, we propose testable hypotheses concerning the social and spatial organisation of the last common ancestor to the extant Antilopini, and certain of its predecessors.

\section{Study areas and methods}

\section{Study areas}

The study was conducted in the region of Aser-Jog, the only area where the beira occurs in the Republic of Djibouti (Laurent et al. 2002), to the southeast of the town of AliSabieh $\left(11^{\circ} 09^{\prime} \mathrm{N} ; 42^{\circ} 42^{\prime} \mathrm{E}\right)$. The region has a tropical arid climate, with a mean annual temperature ca. $30^{\circ} \mathrm{C}$ and mean annual rainfall ca. $250 \mathrm{~mm}$ p.a. (Laurent and Laurent 2002). It includes ca. $145 \mathrm{~km}^{2}$ of low mountains divided into 13 massifs. With an elevation of $600-1,300 \mathrm{~m}$ above sea level, these mountains support a very sparse vegetation cover, mainly composed of small Acacia etbaica trees, shrubs of Croton somalensis and Iphionopsis rotundifolia, and the grass Cymbopogon schoenanthus. The local Issas tribe husbands goats (Capra hircus) in the mountains, as well as sheep (Ovis aries) and donkeys (Equus asinus) in the valleys near campsites. Whereas Salt's dik-dik (Madoqua saltiana), Pelzeln gazelle (Gazella dorcas pelzelnii), and the gerenuk (Litocranius walleri) are present in the valleys, the beira, crested porcupine (Hystrix cristata), and rock hyrax (Procavia johnstoni) are the only wild herbivores having a body mass $>1 \mathrm{~kg}$ that inhabit the mountains. In the area, the caracal (Felis caracal) is the only predator of adult beira. Young have additional predators: striped and spotted hyenas (Hyaena hyaena and Crocuta crocuta), the hamadryas baboon (Papio hamadryas), and Verreaux's eagle (Aquila verreauxii).

Data were collected at two different spatial scales. A first set of data, relative to the beira's grouping pattern, was collected on the occasion of a census of the species that we conducted over the whole range of Aser-Jog (Giotto et al. 2009). A second set, aiming at investigating social and spatial organisation in a small area where a number of beira could be individually recognised, was collected inside the only massif of Addaoua Bourale, located at the southeastern end of the range, to the east of the village of Assamo $\left(10^{\circ} 59^{\prime} \mathrm{N}\right.$; $\left.42^{\circ} 50^{\prime} \mathrm{E}\right)$. With an elevation of $600-850 \mathrm{~m}$ above sea level, this study area covered $4 \mathrm{~km}^{2}$.

\section{Data collection}

Generally speaking, data were collected during daytime by direct observation, using $10 \times 40$ binoculars and a $\times 20$ telescope. Beira $<50 \mathrm{~m}$ apart were considered as members of the same group. Individuals were assigned to five agesex classes: adult females, adult males, sub-adult males, horned young, and polled young. Adult females were distinguished from the other classes by the absence of horns and their greater body size (Dorst and Dandelot 1970). Males of adult size were classified as adults or subadults according to whether the height of the horns was $\geq$ or $<$ that of the ears; when in the same group, sub-adult males also looked a little more slender than adult males. Finally, individuals were classified as young when smaller than adults. In the beira, adult body size is reached at an age of about 12 months (Hammer and Hammer 2005), and horns become visible in young males at an age of 4 to 5 months (C. Hammer, pers. comm.).

The census that provided data on grouping patterns took 69 days of observation between October 2005 and June 2006. Observations were performed from 347 observation posts located on the crests of the 13 massifs of Aser-Jog. At each observation post two observers (NG and a local shepherd) tried to sight beira groups for $1 \mathrm{~h}$. 
Unit A

Late Sep. - Dec. 2006

Addaoua Bourale
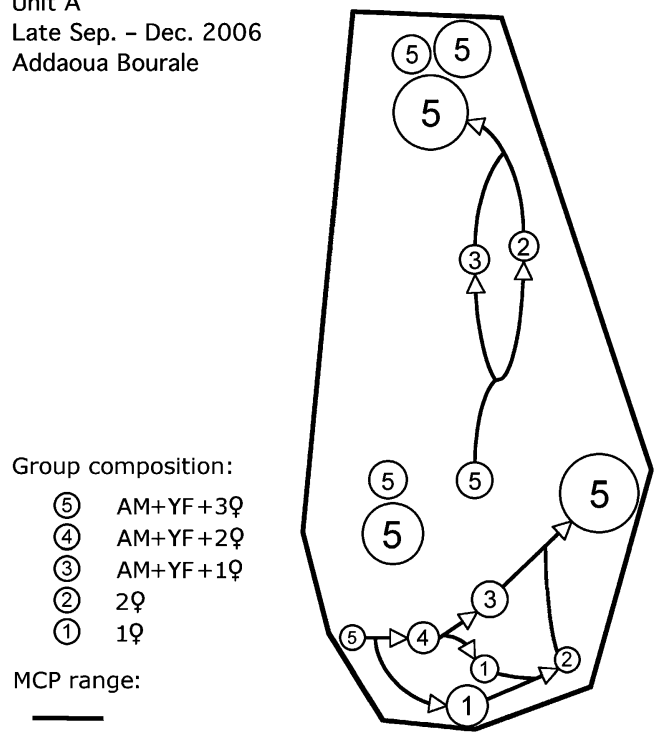

Fig. 1 Determination of the composition of a socio-spatial unit including few recognisable individuals, using both the composition of the groups in which these individuals were sighted, and the dynamics of group fusion and fission observed. In the present case, the unit included a recognisable adult male (AM), a recognisable young female (YF), and three indistinguishable adult females. Each group observed is figured by a circle approximately located in the middle of the recorded route, and whose area is proportional to observation time. Each arrow net shows the dynamics of group fusion and fission monitored within a single day

Data on social and spatial organisation in Addaoua Bourale were recorded for ten sessions of 12 days, regularly distributed from late September 2006 to mid-July 2007. During this campaign, the observations were performed from 16 fixed observation posts, distributed along three walking trails located on the upper third of the slopes. One trail was walked per day, and the three trails were walked four times per session, alternatively in one direction then the other. A single observer (NG) stayed for $1 \mathrm{~h}$ at the first observation post, then, went to the next if no beira were sighted. Otherwise, each group sighted (solitary beira included) was monitored as long as possible, using both scan- and all-occurrence sampling methods (Altmann 1974): every $5 \mathrm{~min}$, a record was made of the location and composition of the group, and between the scans, all the interactions occurring among the monitored beira were noted. Locations were first recorded on a sketch map, then positioned using Garmin 12 GPS after the animals' departure. Owing to the small number of animals in Addaoua Bourale study area, more than half of the beira observed were individually recognised on the basis of variations in colour pattern (white ring around the eyes, dark band across the flank) and morphology (mainly ear and tail shape for females, and horn size and shape for males). Accordingly, the group composition recorded included the identity of the recognisable animals. When not recognisable, a sighted individual was simply characterised by its age-sex class.

Data analysis

For the study of the social and spatial organisation in Addaoua Bourale, individuals using the same home range and frequently observed in the same groups were considered as forming a single socio-spatial unit. Since all the animals from the study area were not individually recognisable, unit composition was determined, using both the composition of the groups in which the recognisable individuals were sighted, and the dynamics of group fusion and fission monitored over single days (Fig. 1). This method was applicable owing to the strong tendency of the members of a unit to gather into a single group. The surface area used by a unit was estimated, applying the minimum convex polygon (MCP) method (Mohr 1947) to the locations of all its members. Assimilating the time during which a group remains cohesive to a lifetime (Pays et al. 2007), we further used the Kaplan-Meier method to estimate the groups' survival curve (Cox and Oakes 1984). This technique is suitable for samples including incomplete lifetimes (i.e., lifetimes of groups whose beginning and/or end by fission or fusion with another group was unobserved). Such data are "censored", so that no effective ending event is counted at the end of the corresponding lifetimes.

\section{Results}

Grouping pattern over the whole range of Aser-Jog

Six among the 13 massifs of Aser-Jog provided no beira sightings during the census, whereas the seven others

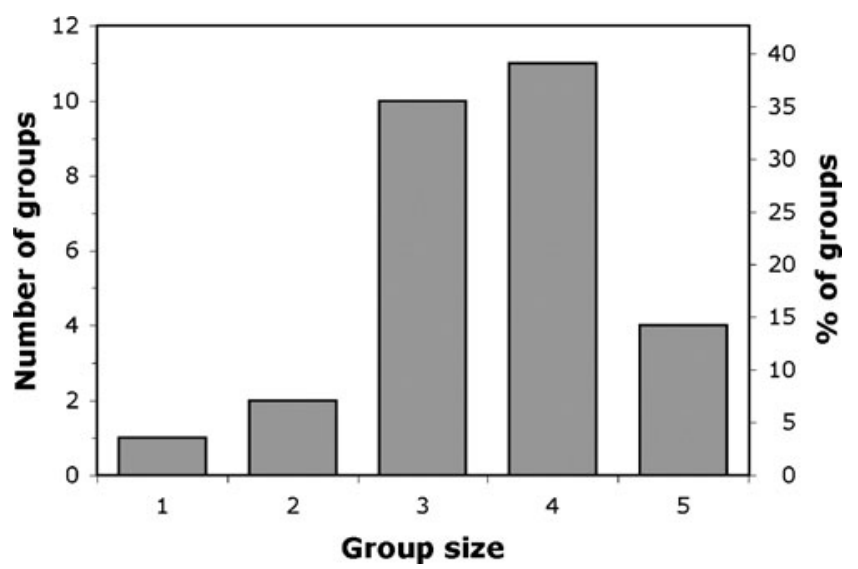

Fig. 2 Size of the 28 beira groups sighted during the census over the whole range of Aser-Jog 
allowed 28 different beira groups to be observed (Giotto et al. 2009). Over the latter seven massifs, we found a positive but insignificant correlation between mean group size and estimated beira density (Kendall's rank correlation: $\tau=0.39$; $n=7 ; P>0.20$ ).

Fig. 3 Group sizes observed in each socio-spatial unit of the beira population studied in Addaoua Bourale, when excluding the young born in the course of the study. Circle area is proportional to group size observation time. $H$ presence of a neonate in the "hider" stage; Oe presence of a female in oestrus. Though member of unit $\mathrm{C}$, the female in oestrus in February visited unit $\mathrm{D}$, and an encounter between the two units occurred
The 28 groups sighted included from one to five beira (mean $\pm S D=3.54 \pm 0.96$ ), three or four on most instances (Fig. 2). The only solitary individual observed was an adult male. The two- to five-sized groups whose age-sex class composition could be determined $(n=22)$ were all mixed-
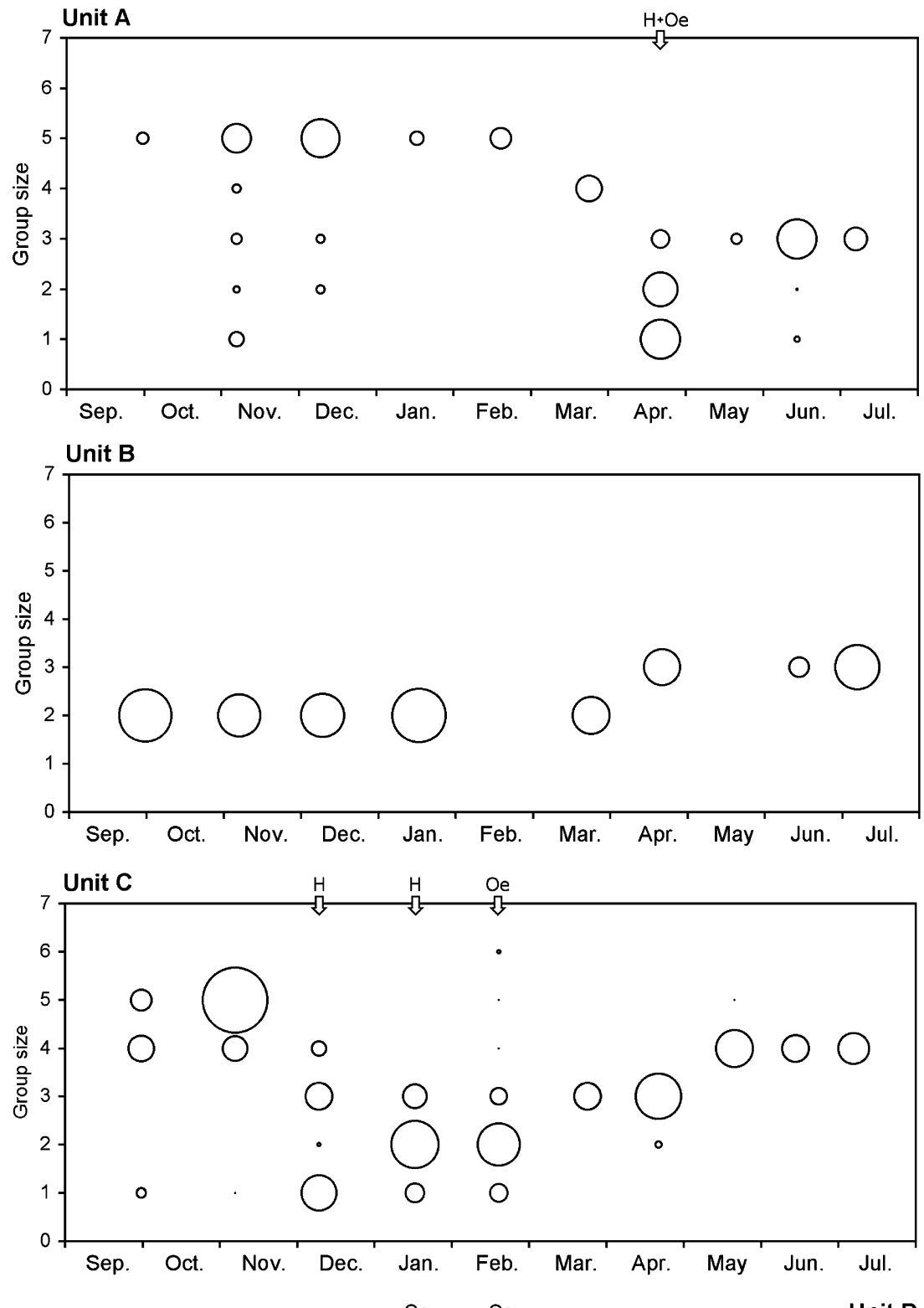

TIME SCALE
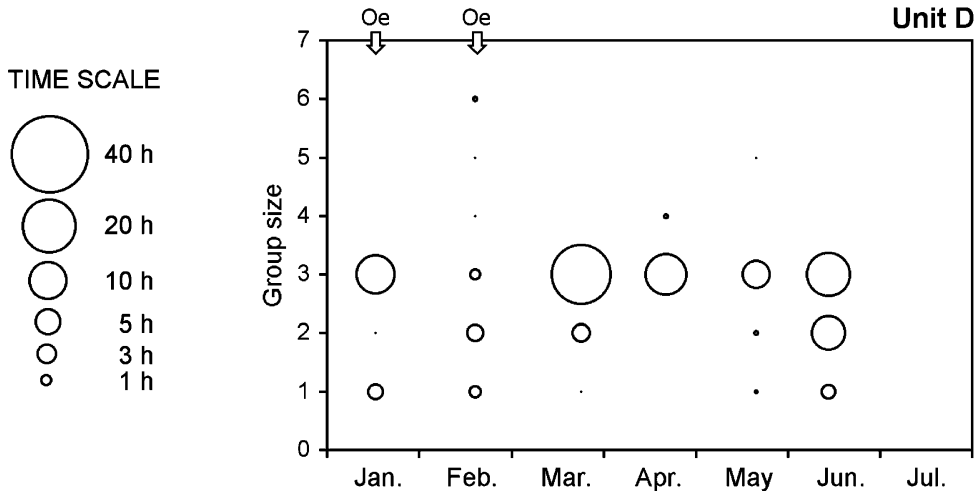
sex groups including a single adult male, from one to three adult females (mean: 1.7), from zero to one sub-adult male (mean: 0.2), and from zero to two young (mean: 0.7). Because of the circumstances of observation, two sighted groups had a composition wholly undetermined, and three included an individual of undetermined age-sex class. Otherwise, the three latter groups included an adult male, from one to two adult females (mean: 1.4), and from zero to one young (mean: 0.6).

\section{Social and spatial organisation in Addaoua Bourale}

A total of $497 \mathrm{~h}$ and 40 min of observation were carried out in the Addaoua Bourale study area, with on average 1.09 beira groups (3.36 individuals) monitored per hour of observation. Owing to the small number of animals, the high proportion of those that were individually recognisable (58-80\% throughout the study), and the monitoring of daily group dynamics, the studied population appeared to be composed of a small number of socio-spatial units.

\section{Changes in unit number, size, and composition}

Figure 3 shows the group sizes observed in each sociospatial unit for each observation session. As the members of any unit exhibit a strong tendency to gather into a single group, the figure also shows the changes in the size of the units that occurred in the course of the study.

At the beginning of the study, the population included three units (total: 12 individuals). Unit "A" included an adult male, three adult females, and a young female (estimated age: 8-10 months); unit "B" included an adult of each sex; and unit "C" was composed of an adult male, two adult females, and two sub-adult males (estimated age: 12-15 months).

In late December, as the two sub-adult males reached adulthood, one of them became the only male of unit $\mathrm{C}$. The elder male went further east, founding a new unit, " $D$ ", with an adult female and her female offspring, both

Table 1 Percentage of time during which all the beira of a sociospatial unit (neonates excluded) made up a single group. Hidden neonate: observation sessions during which the unit included a neonate in the "hider" stage; female in oestrus: sessions during which newcomers. The third male from unit $\mathrm{C}$, henceforward "male E", moved towards the southeast and remained solitary. Departures and entrances of females also occurred. Unit A lost a female between February and March, then another between March and April. The latter was probably the female that entered unit B at the same time. Between April and May, unit $\mathrm{C}$ also gained an additional adult female. Moreover, three births occurred: one within unit $\mathrm{C}$ in early December (but the newborn young was no longer observed in the following months), a second within the same unit in early January, and a third within unit A in April.

As a consequence of the events listed, the population at the end of the study included four units and a solitary male (total: 16 individuals): unit $\mathrm{A}$, composed of an adult male, two adult females and a 3-month-old lamb; unit B, including an adult male and two adult females; unit $\mathrm{C}$, composed of an adult male, three adult females and a $6 \frac{1}{2-}$ month-old young female; unit $\mathrm{D}$, composed of an adult male, and two adult females (including a young adult whose age was estimated at $12-15$ months); and finally solitary male E.

\section{Group lifetime}

On average, the members of a unit made up a single group during $76 \%$ of the observation time. This reached $92 \%$ when the observation sessions during which a neonate was in the "hider" stage or a female in oestrus (Table 1) were excluded. Indeed, groups including all the members of a unit were viable much longer than those including only part of them (Fig. 4). However, when a lamb was hidden, the frequent and prolonged absence of the neonate's mother increased the lifetime of incomplete groups (Fig. 4). Moreover, group lifetime might be shortened when a female was in pro-oestrus (Fig. 4). This was the case in February when the pro-oestrous female, though member of unit $\mathrm{C}$, visited unit $\mathrm{D}$ (whose male was formerly the elder male from unit $\mathrm{C}$ ). No such behaviour and consecutive

no neonate was in the "hider" stage but a female was in oestrus; otherwise: sessions during which there were neither a hidden neonate, nor a female in oestrus. Unit size and composition are given excluding the young born in the course of the study

\begin{tabular}{|c|c|c|c|c|c|c|}
\hline \multirow[t]{2}{*}{ Unit } & \multirow[t]{2}{*}{ Unit size } & \multirow[t]{2}{*}{ Unit composition } & \multicolumn{4}{|c|}{ Percentageof time unit members were altogether } \\
\hline & & & Hidden neonate & Female in oestrus & Otherwise & Total \\
\hline A & $3-5$ & 1 ○े $2-4$ 우 & 14 & - & 94 & 72 \\
\hline B & $2-3$ & 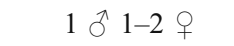 & - & - & 100 & 100 \\
\hline $\mathrm{C}$ & $3-5$ & $1-3$ ๙ $2-3$ 우 & 16 & 16 & 87 & 58 \\
\hline $\mathrm{D}$ & 3 & $1 \lesssim 2$ 우 & - & 74 & 82 & 80 \\
\hline Total & & & 15 & 40 & 92 & 76 \\
\hline
\end{tabular}


a

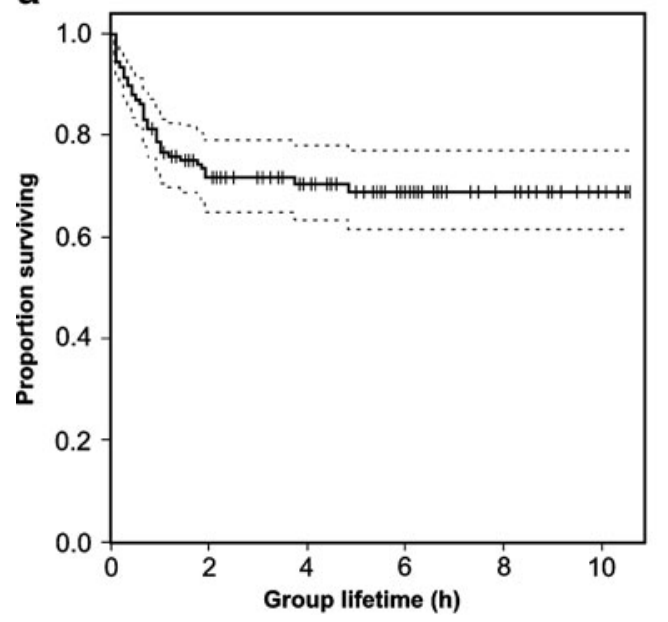

b

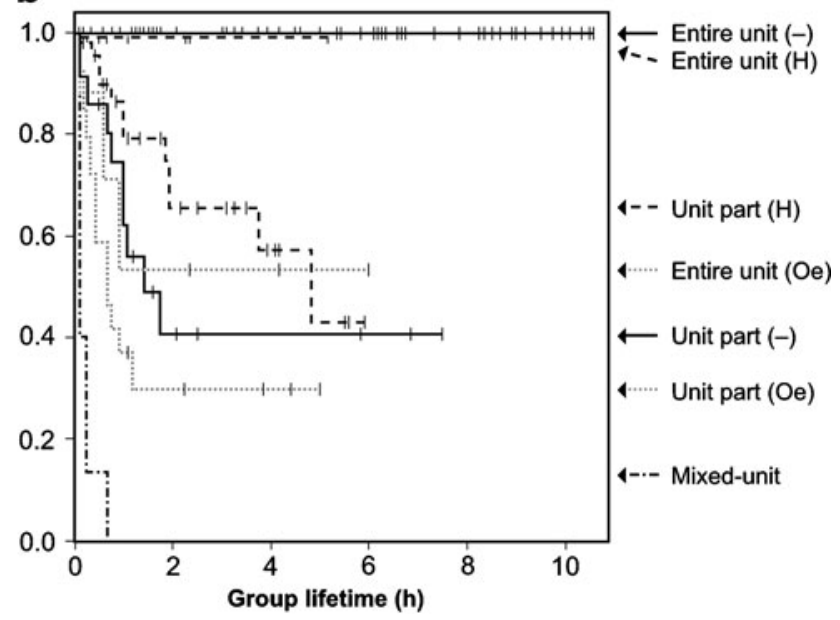

Fig. 4 a Survival curve (and 95\% confidence limits) of the 215 beira groups monitored in Addaoua Bourale. b Survival curves obtained when distinguishing several group types and situations. Entire unit: groups including all the members of a unit (neonates excluded). Unit part groups including only some members of a unit. Mixed-unit groups including members of two different units. $H$ observation

alteration of the group dynamics were observed in January when the adult female of unit D was in oestrus (Fig. 3).

\section{Unit ranges}

Figure 5 shows the MCP ranges of the socio-spatial units before and after the increase in unit number in late sessions during which the unit included a neonate in the "hider" stage. Oe sessions during which no neonate was in the "hider" stage but a female was in oestrus. - sessions during which there were neither a hidden neonate, nor a female in oestrus. Vertical marks on the survival curves correspond to censored data

December. Overall, the ranges overlapped little and tended to make up an intricate mosaic: the part common to the polygons of units A and B was actually only used by the members of unit A. Nevertheless, the ranges of unit $\mathrm{D}$ and of solitary male $\mathrm{E}$ still partly overlapped that of unit $\mathrm{C}$, from which $\mathrm{E}$ and the male of unit $\mathrm{D}$ recently departed.
Fig. 5 MCP ranges of the beira socio-spatial units in Addaoua Bourale study area before and after the increase in unit number. Whatever the period, the intersection between the polygons of units $\mathrm{A}$ and $\mathrm{B}$ was only used by unit A. Excluding this intersection from the range of unit $\mathrm{B}$ leads to estimates of $0.49,0.56$, and $0.90 \mathrm{~km}^{2}$ for the ranges of units $\mathrm{A}, \mathrm{B}$, and $\mathrm{C}$ in the first period, and $0.41,0.61$, and $0.61 \mathrm{~km}^{2}$ for the ranges of the same units in the second period. The ranges of unit $\mathrm{D}$ and solitary male $\mathrm{E}$ are incomplete. The compositions indicated are those of the units in late Sep. and midJuly, respectively. Ŝadult or sub-adult male; $\varnothing$ adult female; - young; grey crosses crest; grey line wadi; black sinuous line "defecation walk" performed by an adult male (see main text, "Possible marking behaviour" section)

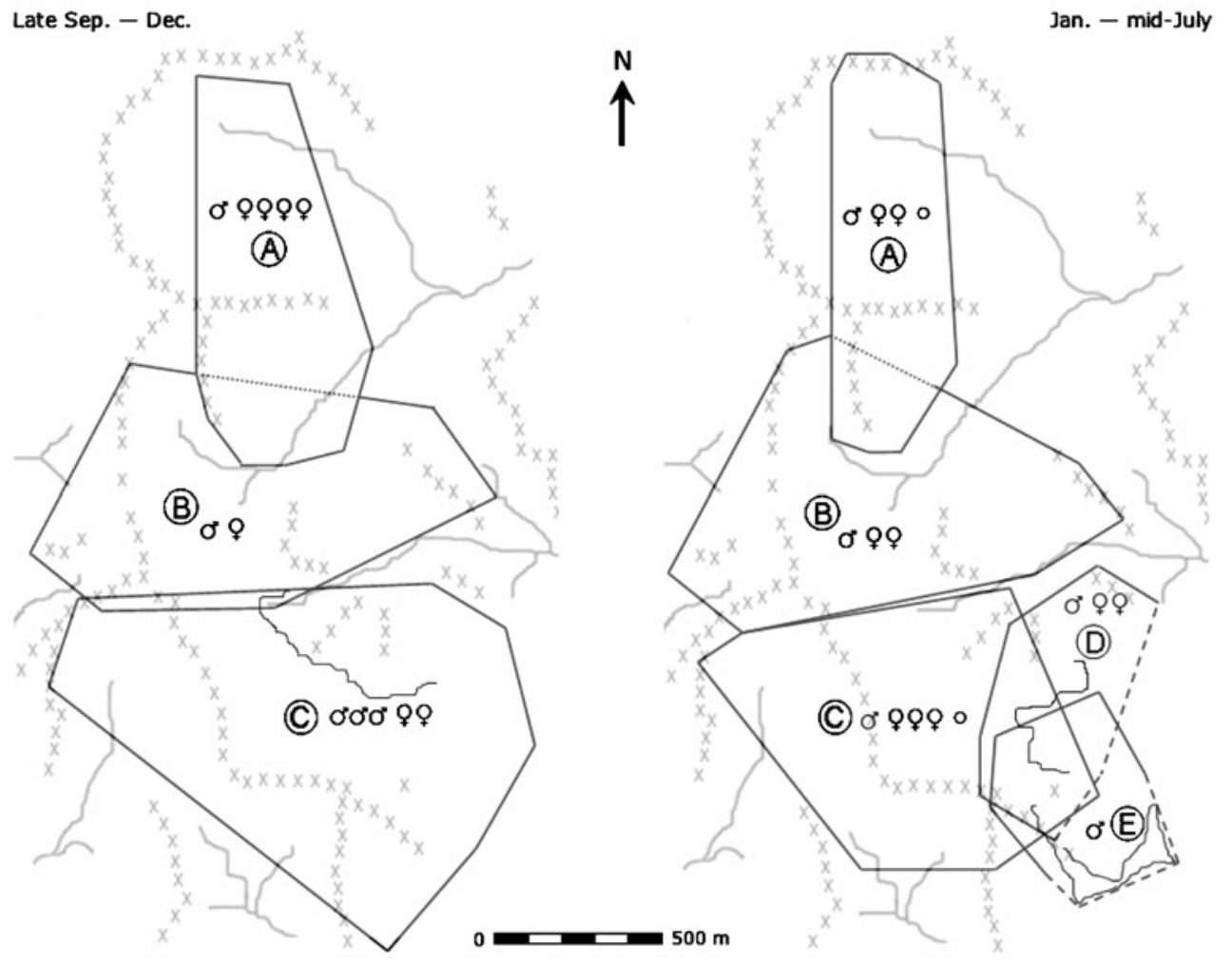


For the 10 months of study, when excluding the part covered by unit $\mathrm{A}$ from the polygon of unit $\mathrm{B}$, the areas used by units $\mathrm{A}, \mathrm{B}$, and $\mathrm{C}$ were estimated at 0.66 , 0.59 , and $0.83 \mathrm{~km}^{2}$, respectively (mean $\pm \mathrm{SD}: 0.69 \pm$ $0.12 \mathrm{~km}^{2}$ ). For the same period, solitary male $\mathrm{E}$ and the adult male that shifted from unit $\mathrm{C}$ to unit $\mathrm{D}$ had larger MCP ranges (0.96 and $0.98 \mathrm{~km}^{2}$, respectively). However, their ranges between January and mid-July (as well as those of the females from unit D) undoubtedly extended further south and east (Fig. 5), and were thus clearly underestimated.

\section{Contact between units}

Members of different units were observed in contact (i.e., in the same group) during a total of $1 \mathrm{~h}$ and $45 \mathrm{~min}$ (i.e., $0.35 \%$ out of the total time of observation). Five contacts were actually recorded, and all involved individuals that were still and/or had previously been in unit $\mathrm{C}$.

The only contact that included all the members of units $\mathrm{C}$ and D occurred in February while an adult female from unit $\mathrm{C}$ was in pro-oestrus. At the beginning of the observation, this female was actually with the three members of unit D. On the encounter between this group and the group including the other members of unit $\mathrm{C}$ (including the young born in early January), smelling of outsiders was frequent, but avoidance too, and the adult females, unusually nervous, often pursued an individual over short distances; the adult female from unit $\mathrm{D}$ even chased the pro-oestrous female vehemently. Then, the male from unit $\mathrm{C}$ focused on the latter female, following her closely and attempting mounts. As the other male did not try to interfere, no agonistic interactions occurred between the two males.

The four other contacts observed involved an adult male on the one hand, and a variable number of members of a unit on the other. On one occasion (in April), solitary male $\mathrm{E}$ approached the members of unit $\mathrm{D}$, smelled the two females who avoided him, smelled their faeces, and left without being bothered by the male of unit D. On another occasion (in May), the male from unit D left his group and walked towards the members of unit $\mathrm{C}$. He smelled one of the two adult females, and approached the other who avoided him. The adult male of unit $\mathrm{C}$ then rushed towards him, and after a symmetrical head-to-head butt, pursued him over $10 \mathrm{~m}$. Contact ended as the male of unit D walked back to the females of his group. On the two remaining instances (that both occurred in February, while the female of unit $\mathrm{C}$ was pro-oestrous), solitary male $\mathrm{E}$ was still at a distance from the members of unit $\mathrm{C}$ when he was chased away by the male of the unit.

\section{Possible marking behaviour}

Males were never seen horning or rubbing their face against vegetation. In contrast, collective sequences of linked urination-defecation were common. Very often, indeed, linked urination-defecation by an adult female triggered the same behaviour in other group members at the same place, the adult male typically ending the sequence. These "collective dunging ceremonies" occurred anywhere in the unit's range, or in regularly used latrines that were rather rarely located on the borders of the range. In addition to the collective urination-defecation sequences, on three instances we observed an adult male walking alone at a regular pace without foraging, but stopping approximately every 2 min to defecate without urinating or scraping the ground. Solitary male E behaved so almost without interruption for $1 \mathrm{~h}$ and $10 \mathrm{~min}$ in March. The adult male from units $\mathrm{C}$ then D was observed performing the same behaviour over $35 \mathrm{~min}$ in December and $55 \mathrm{~min}$ in January, in each case just after having left the other members of his current unit. At least in these two instances, the "defecation walk" was not especially performed near the boundaries of the unit's range (Fig. 5).

\section{Discussion}

\section{Socio-spatial organisation of the beira}

Our results suggest that in the whole range of Aser-Jog beira live in socio-spatial units that include a single adult male, and from one to three adult females. Within a given area, unit ranges tend to form an intricate mosaic of territories. Moreover, the members of a unit make up a single group during most of the time, though splitting into two groups or more (some necessarily all-female) becomes more frequent when a neonate is in the "hider" stage, and sometimes also when an adult female is in oestrus.

Though unit size possibly tends to increase with population density (as is the case in the oribi; Arcese et al. 1995), we suspect that the groups of up to 12 beira sometimes quoted in the literature (Walther 1990) were actually transient groups formed when the members of two neighbouring units made an encounter. In our observations, such encounters were very rare. It therefore seems improbable that the mosaic of territories recorded in the present study primarily resulted from direct interactions between neighbouring units, even though chasing behaviour between adult males does seem to be rather frequent on encounter. Space partitioning between socio-spatial units likely relies upon scent marks, and primarily upon faeces since the beira is devoid of any scent glands other than interdigital (Estes 1991). In many Antilopini, including dik- 
diks and the oribi, territory maintenance involves preorbital-gland and/or faecal scent marking (Walther 1965, 1978; Hendrichs 1975; Dubost and Feer 1981; Gosling 1981; Ono et al. 1988; Estes 1991; Brashares and Arcese 1999a, 1999b). In most cases, however, the regularly used latrines are reported to be located along territory borders, whereas in this study we found no evidence of such a pattern in the beira.

In the Addaoua Bourale study area, unit composition sometimes changed because of the departure or arrival of individuals. As could be expected on the basis of unit composition, male departures were observed when young males within a unit reached adulthood. However, departures and arrivals of females (sometimes followed by their young) were also recorded. Because of the small size of the study area, and the small number of individually recognisable beira, dispersal distance could not be accurately estimated. However, two local shepherds with whom we worked reported having observed on three instances, in May 2007, beira crossing the 150-m wide flat-bottomed wadi between Addaoua Bourale and the massif of Godire, located on the Ethiopian side of the border. So, dispersal seemed sufficient for exchanges of individuals to occur between Addaoua Bourale and the neighbouring massifs (Godire to the South, Boura to the North; see Giotto et al. 2009).

\section{Comparison with the other Antilopini}

The social and spatial organisation of the beira definitely differs from those of the "non-dwarf" Antilopini, be this the typical "Gazella-like" organisation described in the "Introduction" section, or more atypical ones such as that of the Mongolian gazelle (Procapra gutturosa), in which males never seem to be territorial, and individuals often gather into large, unstable, mixed-sex herds (Heptner et al. 1989; Schaller 1998). Among dwarf Antilopini, the beira's social and spatial organisation also differs radically from that of the steenbok and grysboks, whose individuals are usually solitary (Estes 1991; Cloete and Kok 1990; Skinner and Chimimba 2005). In contrast, it appears much more similar to those of the dik-diks and oribi, which are reported to live in small and fairly cohesive mixed-sex units whose respective territories are primarily defended by males (Monfort and Monfort 1974; Hendrichs 1975; Arcese et al. 1995; Brotherton and Rhodes 1996).

Interestingly, the dik-diks, oribi, and beira are also the only Antilopini to perform collective sequences of linked urination-defecation (Giotto et al. 2008). In the dik-diks and oribi, as in the beira, these sequences are typically initiated by females and ended by males, the former rarely scraping the ground, the latter doing so before urinating and defecating, so it is only their faeces that remain intact on the ground's surface (Monfort and Monfort 1974; Hendrichs 1975; Giotto et al. 2008). In the steenbok and grysboks, males and females perform linked urinationdefecation separately since they are solitary most of the time; and at least in the steenbok, the two sexes scrape the ground not only before but also after defecating, so that no faeces remain undisturbed on the ground (Walther 1990; Estes 1991; Skinner and Chimimba 2005). Among the nondwarf Antilopini, linked urination-defecation is absent in the Mongolian gazelle, and possibly the saiga (Saiga tatarica), whereas in the other species, it is only performed by adult males, possibly preceded but rarely followed by the scraping of the ground (Estes 1967, 1991; Dubost and Feer 1981; Schaller 1998).

Beyond their behavioural similarities, the three genera Dorcatragus, Madoqua, and Ourebia exhibit clear differences, especially with respect to unit composition. In the dik-diks, socio-spatial units include a single adult male as in the beira, but exceptionally more than one adult female (Hendrichs 1975; Brotherton and Manser 1997). On the other hand, in high-density populations of the oribi, units can include several adult females, as we observed in the beira, but also several adult males (Arcese et al. 1995; Brashares and Arcese 1999a).

The three genera might also differ with respect to unit cohesiveness. In a population of Kirk's dik-dik (Madoqua kirkii), Brotherton and Rhodes (1996) found that the adults of a unit made up a single group $77 \%$ of the time when no neonate was in the hider stage and no female was in oestrus. A higher value $(92 \%)$ was obtained for the beira in the present study. Moreover, Arcese et al. (1995) performed a similar estimate in an oribi population, except that they included birthing and mating periods in their calculation, and the computed percentage decreased regularly from 72 to $22 \%$ as the number of adults in the unit increased from two to five. A qualitatively similar decline is possible in the beira, but in our study, the values obtained for the units monitored averaged $76 \%$, all sizes pooled, and were never lower than $50 \%$. These differences in unit cohesiveness should, however, be considered with caution. The habitats in which the dik-diks, oribi, and beira are found differ considerably in openness, and the distance at which conspecifics can perceive one another necessarily modulates the frequencies with which the different group sizes possible in a population or a socio-spatial unit occurred (Gerard et al. 2002; Pays et al. 2007).

Sketching the social and spatial organisation of the ancestors

With the data provided for the beira, the present work confirms that the social and spatial organisations exhibited by the morphologically conservative genera Raphicerus, 
Madoqua, Ourebia, and Dorcatragus differ radically from those of the other Antilopini but also substantially from one another. The question then arises as to what may have been the social and spatial organisation of the last common ancestor to the Antilopini.

As currently resolved, the phylogeny of the Antilopini does not suggest any answer. Eight extant genera of nondwarf Antilopini (Antidorcas, Ammodorcas, Litocranius, Antilope, Nanger, Gazella, Eudorcas, and Saiga) are considered as forming a monophyletic group (Hernández Fernández and Vrba 2005; Ropiquet 2006). Molecular analyses further suggest that Dorcatragus and Madoqua also constitute a clade (Ropiquet 2006). But unfortunately, the relationships between the two previous clades and each of the three remaining genera (Raphicerus, Ourebia, and the non-dwarf Procapra) remain unclear (Hernández Fernández and Vrba 2005; Ropiquet 2006). However, what is more generally known of the phylogeny, ecology, and social behaviour of the extant bovids provides clues on the social and spatial organisation of the last common ancestor to the Antilopini, and certain of its predecessors.

According to recent molecular phylogenies (Fig. 6), the tribe Antilopini has, for sister-clade, either the tribe Reduncini (reedbucks and relatives), or a clade gathering the klipspringer (Oreotragus oreotragus), and the tribe Cephalophini (duikers). Now, these two possible sisterclades seem to have evolved from rather similar starting points.

Most of the extant Reduncini are wetland-dwellers. Two species, however, inhabit plateaus and stony slopes with scattered bushes: the mountain reedbuck (Redunca fulvorufula), and the rhebok (Pelea capreolus), alone in its genus, and considered as the most morphologically conservative species (Gentry 1992), and the most basal stem of the tribe (Gatesy et al. 1997; Hassanin and Douzery 1999; Matthee

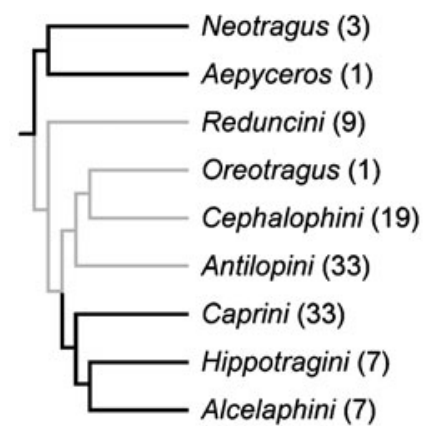

Hassanin and Douzery (1999) Agnarsson and May-Collado (2008) (Cytochrome b gene)

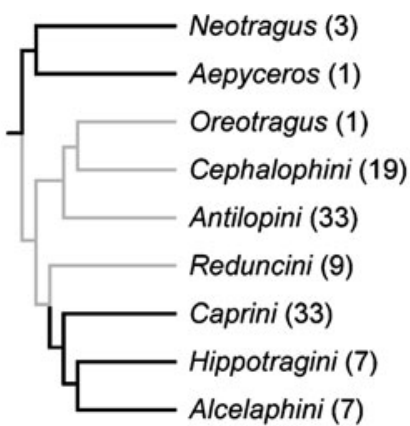

Matthee and Davis (2001)

( 3 mitochondrial genes and 4 nuclear DNA fragments)
Fig. 6 Molecular phylogenies of the basal clades of the Antilopinae established by Hassanin and Douzery (1999), Matthee and Davis (2001), Ropiquet and Hassanin (2005), Ropiquet (2006), and Agnarsson and May-Collado (2008). Between brackets number and Davis 2001; Hernández Fernández and Vrba 2005; Ropiquet 2006; Agnarsson and May-Collado 2008). Generally speaking, males only are territorial in the Reduncini. The wetland-dwelling species make up unstable groups and as a whole display a variety of social and spatial organisations, ranging from an almost solitary to a highly gregarious life, through a Gazella-like organisation (Estes 1991). The latter organisation is also found in the mountain reedbuck (Skinner and Chimimba 2005; Taylor et al. 2007). But the scheme is very different in the rhebok. The species actually exhibits an organisation that recalls that of the beira: in addition to the absence of bachelor groups, it lives in very cohesive mixed-sex units including a single adult male and from one to five adult females (Estes 1991; Skinner and Chimimba 2005; Taylor et al. 2007). In contrast to the males of the other Reduncini, which do not exhibit any marking behaviour, rhebok males further perform "defecation walks" similar to those we observed on rare occasions in the beira (Estes 1991; Skinner and Chimimba 2005; Taylor and Skinner 2006).

Almost all the Cephalophini are forest-dwellers, including those of the genus Philantomba that constitutes the most basal stem of the tribe (van Vuuren and Robinson 2001; Ropiquet 2006). Nonetheless, the klipspringer inhabits half-open rocky areas (Estes 1991; Skinner and Chimimba 2005) suggesting forest was possibly not the habitat of the last common ancestor to the clade Oreotragus-Cephalophini. In the klipspringer, the two Philantomba spp., and likely a number of Cephalophus spp., both adult males and females chase off same-sex outsiders (Ralls 1975; Dunbar and Dunbar 1980; Dubost 1983; Estes 1991). Furthermore, most of the Cephalophini live solitary or in loose couples (Dubost 1983; Estes 1991), but in the basal genus Philantomba, couples are fairly cohesive, the two members spending ca. $50 \%$ of the time together (Dubost

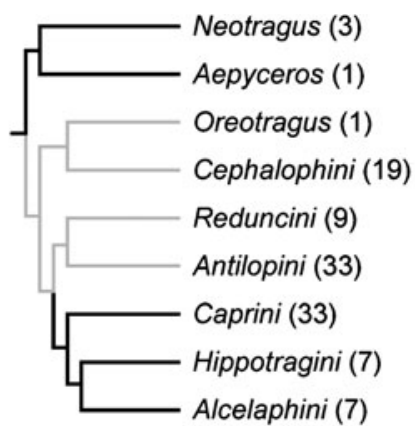

Ropiquet and Hassanin (2005) ( 2 mitochondrial genes and 1 nuclear DNA fragment)
Ropiquet (2006)

( 3 mitochondrial genes and 4 nuclear DNA fragments)

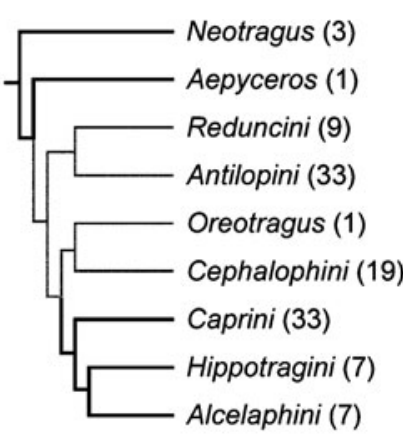

of species according to Hernández Fernández and Vrba (2005). In grey paraphyletic set including the tribe Antilopini, and its two possible sister-clades, i.e., the tribe Reduncini, and the clade Oreotragus-Cephalophini 
1980, 1983). Cohesiveness, however, culminates in the klipspringer: the species lives in couples, or in singlemale trios, whose members make up a single group during a percentage of time estimated at $87 \%$ by Dunbar and Dunbar (1974). With respect to unit size and cohesiveness, the klipspringer thus resembles an intermediate between the beira and dik-diks. In contrast to what is reported for the Cephalophini (Dubost 1983; Estes 1991), the members of klipspringer units further use latrines (Dunbar and Dunbar 1974).

The previous elements suggest that, whatever their sister-group, the last common ancestor to the Antilopini was a species that dwelt in half-open habitat, and lived in fairly cohesive mixed-sex units including a single adult male, and a small number of adult females. Provided one of the phylogenies summarised in Fig. 6 is correct, the same elements further suggest a similar portrait for the last common ancestor to the Antilopini, Reduncini, Cephalophini, and Oreotragus, and thus to all the extant Antilopinae except the basal genera Neotragus and Aepyceros.

The scheme was probably different for the last common ancestor to all the extant Antilopinae, at least with respect to habitat. The genus Neotragus showing a much more conservative morphology than the impala Aepyceros melampus (Gentry 1992), it constitutes our best approximation as to what was the last common ancestor to the Antilopinae. Now, the three extant Neotragus spp. are forest dwellers inhabiting dense undergrowth in which visibility is especially reduced (Feer 1979; Skinner and Chimimba 2005). Moreover, adult males systematically try to evict same-sex intruders, whereas females seem more tolerant. As a consequence, individuals are primarily sighted alone, but mixed-sex groups including a single male and sometimes more than one female are regularly seen (Feer 1979; Somers et al. 1990; Skinner and Chimimba 2005).

An additional point must be noted. The suni (Neotragus moschatus) and the impala are among the very rare nonAntilopini bovids in which linked urination-defecation is reported (Somers et al. 1990; Vrba and Schaller 2000). The sequence is often performed on latrines in both species, by adult males only and typically without ground scraping in the impala (Leuthold 1970, 1977; Jarman 1979), by the two sexes and sometimes after ground pawing in the suni (Somers et al. 1990). Furthermore, in the suni, linked urination-defecation by the female of a mixed-sex pair triggers the same behaviour in the male (Skinner and Chimimba 2005). So, the collective urination-defecation sequences observed in the beira, dik-diks, and oribi were likely already present in the last common ancestor to all the extant Antilopinae.

Overall, the beira might be, among the Antilopini, the extant species whose social and spatial organisation is the nearest to that of the last common ancestor to the
Antilopini, as well as to that of the last common ancestor to all the extant Antilopinae with the exception of the basal genera Neotragus and Aepyceros. Nevertheless, the possibility remains that in at least one of these two ancestral species, both adult males and females chased off same-sex outsiders, as is currently the case in the klipspringer, a number of duikers, and the steenbok. This would be possible in the elder ancestor if the clade OreotragusCephalophini were definitely found to be the sister-group of all the other Antilopinae but Neotragus and Aepyceros. This would appear very probable in the last common ancestor to the Antilopini if the clade Oreotragus-Cephalophini were definitely found to be the sister-group of the Antilopini, and if Raphicerus appeared as the sister-genus of the other Antilopini. Enhanced resolution of the antelope phylogeny will point out the most likely scenario.

Acknowledgements Special thanks are due to the members of ADDLA (Association de Développement Durable Local d'Aser-Jog), especially Abo Daher Obsieh, Boulboul, Obar, Mohamed, and Yassin for helping and guiding us during the field work, and Alain Laurent and Nicolas Prévôt for initiating this study. We acknowledge Nabil Mohamed from the CERD (Centre d'Etudes et de Recherche de Djibouti), Bertrand Lafrance from DECAN association, and Richard Hansonnet for their consistent support. We thank Catrin Hammer from Al Wabra Wildlife Preservation for providing us information on beira development. Finally, we are grateful to the SCAC/MAE (Service de Coopération et d'Action Culturelle du Ministère des Affaires Etrangères) and the CEPA (Conservation des Espèces et des Populations Animales) for financial support. The whole study complies with current Djiboutian laws.

\section{References}

Agnarsson I, May-Collado LJ (2008) The phylogeny of Cetartiodactyla: the importance of dense taxon sampling, missing data, and the remarkable promise of cytochrome $\mathrm{b}$ to provide reliable species-level phylogenies. Mol Phyl Evol 48:964985

Altmann J (1974) Observational study of behavior: sampling methods. Behaviour 49:227-267

Arcese P, Jongejan G, Sinclair ARE (1995) Behavioural flexibility in a small African antelope: group size and composition in the oribi (Ourebia ourebi, Bovidae). Ethology 99:1-23

Boitani L, Corsi F, De Biase A, D'Inzillo Carranza I, Ravagli M, Reggiani G, Sinibaldi I, Trapanese P (1999) A databank for the conservation and management of the African mammals. Istituto di Ecologia Applicata, Roma

Brashares JS, Arcese P (1999a) Scent marking in a territorial African antelope: I. The maintenance of borders between male oribi. Anim Behav 57:1-10

Brashares JS, Arcese P (1999b) Scent marking in a territorial African antelope: II. The economics of marking with faeces. Anim Behav 57:11-17

Brotherton PNM, Manser MB (1997) Female dispersion and the evolution of monogamy in the dik-dik. Anim Behav 54:14131424

Brotherton PNM, Rhodes A (1996) Monogamy without biparental care in a dwarf antelope. Proc R Soc Lond B 263:23-29 
Cloete G, Kok OB (1990) Aspects of the behaviour of steenbok (Raphicerus campestris) in the Kuiseb River Canyon, S.W.A./ Namibia. J Namib Sci Soc 42:25-45

Cox DR, Oakes D (1984) Analysis of survival data. Chapman and Hall, London

Dorst J, Dandelot P (1970) A field guide to the larger mammals of Africa. Collins, London

Dubost G (1980) L'écologie et la vie sociale du Céphalophe bleu (Cephalophus monticola Thunberg), petit ruminant forestier africain. Z Tierpsychol 54:205-266

Dubost G (1983) Le comportement de Cephalophus monticola Thunberg et $C$. dorsalis Gray, et la place des céphalophes au sein des ruminants $\left(1^{\text {re }}\right.$ partie). Mammalia 47:141-177

Dubost G, Feer F (1981) The behavior of the male Antilope cervicapra L., its development according to age and social rank. Behaviour 76:62-127

Dunbar RIM, Dunbar EP (1974) Social organization and ecology of the klipspringer (Oreotragus oreotragus) in Ethiopia. Z Tierpsychol 35:481-493

Dunbar RIM, Dunbar EP (1980) The pairbond in klipspringer. Anim Behav 28:219-229

Estes RD (1967) The comparative behavior of Grant's and Thomson's gazelles. J Mammal 48:189-209

Estes RD (1991) The behavior guide to African mammals. Univ California Press, Berkeley

Feer F (1979) Observations écologiques sur le néotrague de Bates (Neotragus batesi de Winton, 1903, Artiodactyle, Ruminant, Bovidé) du nord-est du Gabon. Rev Ecol (Terre Vie) 33:159-239

Gatesy J, Amato G, Vrba E, Schaller G, DeSalle R (1997) A cladistic analysis of mitochondrial ribosomal DNA from the Bovidae. Mol Phyl Evol 7:303-319

Gentry AW (1992) The subfamilies and tribes of the family Bovidae. Mamm Rev 22:1-32

Gerard JF, Bideau E, Maublanc ML, Loisel P, Marchal C (2002) Herd size in large herbivores: encoded in the individual or emergent? Biol Bull 202:275-282

Giotto N, Laurent A, Mohamed N, Prevot N, Gerard JF (2008) Observations on the behaviour and ecology of a threatened and poorly known dwarf antelope: the beira (Dorcatragus megalotis). Eur J Wildl Res 54:539-547

Giotto N, Obsieh D, Joachim J, Gerard JF (2009) Population size and distribution of the vulnerable beira antelope Dorcatragus megalotis in Djibouti. Oryx 43:552-555

Gosling LM (1981) Demarkation in a gerenuk territory: an economic approach. Z Tierpsychol 56:305-322

Hammer C, Hammer S (2005) Daten zur Fortpflanzung und Jungtierentwicklung der Beira-Antilope (Dorcatragus megalotis). Zool Gart 75:89-99

Hassanin A, Douzery EJP (1999) The tribal radiation of the family Bovidae (Artiodactyla) and the evolution of the mitochondrial cytochrome $b$ gene. Mol Phyl Evol 13:227-243

Heckel JO, Rayaleh HA, Wilhelmi F, Hammer S (2008) Dorcatragus megalotis. In: IUCN 2008 (ed) 2008 IUCN Red List of Threatened Species <www.iucnredlist.org> Accessed on 19 November 2008

Hendrichs H (1975) Changes in a population of dikdik, Madoqua (Rhynchotragus) kirki (Günther 1880). Z Tierpsychol 38:55-69

Heptner VG, Nasimovich AA, Bannikov AG (1989) Mammals of the Soviet Union, vol 1, Ungulates. EJ Brill, Leiden

Hernández Fernández M, Vrba ES (2005) A complete estimate of the phylogenetic relationships in Ruminantia: a dated species-level supertree of the extant ruminants. Biol Rev 80:269-302

Jarman MV (1979) Impala social behaviour: territory, hierarchy, mating, and the use of space. Paul Parey, Berlin
Künzel T, Künzel S (1998) An overlooked population of the beira antelope Dorcatragus megalotis in Djibouti. Oryx 32:75-80

Laurent A, Laurent D (2002) Djibouti au rythme du vivant: les mammifères d'hier à aujourd'hui pour demain. Beira CFP, Toulouse

Laurent A, Prévot N, Mallet B (2002) Original data in ecology, behaviour, status, historic and present distribution of the Beira Dorcatragus megalotis (Bovidae: Antilopinae) in the Republic of Djibouti and adjacent territories of Somalia and Ethiopia. Mammalia 66:1-16

Leuthold W (1970) Observations on the social organization of impala (Aepyceros melampus). Z Tierpsychol 27:693-721. Cambridge University Press: Cambridge

Leuthold W (1977) African ungulates. A comparative review of their ethology and behavioral ecology. Springer, Berlin

Matthee CA, Davis SK (2001) Molecular insights into the evolution of the family Bovidae: a nuclear DNA perspective. Mol Biol Evol 18:1220-1230

Mohr CO (1947) Table of equivalent populations of North American small mammals. Am Midl Nat 37:223-249

Monfort A, Monfort N (1974) Notes sur l'écologie et le comportement des oribis (Ourebia ourebi, Zimmerman, 1783). Rev Ecol (Terre Vie) 28:169-208

Ono Y, Doi T, Ikeda H, Baba M, Takeishi M, Izawa M, Iwamoto T (1988) Territoriality of Guenther's dikdik in the Omo National Park, Ethiopia. Afr J Ecol 26:33-49

Pays O, Benhamou S, Helder R, Gerard JF (2007) The dynamics of group formation in large mammalian herbivores: an analysis in the European roe deer. Anim Behav 74:1429-1441

Ralls K (1975) Agonistic behavior in Maxwell's duiker, Cephalophus maxwelli. Mammalia 39:241-249

Ropiquet A (2006) Étude des radiations adaptatives au sein des Antilopinae (Mammalia, Bovidae). PhD thesis. Univ Paris 6, Paris

Ropiquet A, Hassanin A (2005) Molecular phylogeny of caprines (Bovidae, Antilopinae): the question of their origin and diversification during the Miocene. J Zool Syst Evol Res 43:49-60

Schaller GB (1998) Wildlife of the Tibetan steppe. Univ Chicago Press, Chicago

Skinner JD, Chimimba CT (2005) The mammals of the Southern African subregion. Cambridge Univ Press, Cambridge

Somers M, Rasa OAE, Apps PJ (1990) Marking behaviour and dominance in Suni antelope (Neotragus moschatus). Z Säugetierkd 55:340-352

Taylor WA, Skinner JD (2006) Two aspects of social behaviour in grey rhebok: scent marking and submission. S Afr J Wildl Res 36:183-185

Taylor WA, Skinner JD, Krecek RC (2007) Home ranges of sympatric grey rhebok and mountain reedbuck in a South African highveld grassland. Afr Zool 42:145-151

van Vuuren BJ, Robinson TJ (2001) Retrieval of four adaptive lineages in duiker antelope: evidence from mitochondrial DNA sequences and fluorescence in situ hybridization. Mol Phyl Evol 20:409-425

Vrba ES, Schaller GB (2000) Phylogeny of Bovidae based on behavior, glands, skulls, and postcrania. In: Vrba ES, Schaller GB (eds) Antelopes, deer, and relatives. Fossil record, behavioral ecology, systematics, and conservation. Yale Univ Press, New Haven, pp 203-222

Walther FR (1965) Verhaltensstudien an der Grantgazelle (Gazella granti Brooke, 1872) im Ngorongoro-Krater. Z Tierpsychol 22:167-208

Walther FR (1978) Mapping the structure and the marking system of a territory of the Thomson's gazelle. E Afr Wildl J 16:167-176

Walther FR (1990) Duikers and dwarf antelopes. In: Parker SP (ed) Grzimek's encyclopedia of mammals, vol 5. McGraw-Hill, New York, pp 325-343 